\title{
СУЧАСНИЙ СТАН ГОТЕЛЬНОГО ГОСПОДАРСТВА В ЗАКАРПАТСЬКІЙ ОБЛАСТІ ТА ПРОГНОЗУВАННЯ ЙОГО РОЗВИТКУ
}

\begin{abstract}
У статті проаналізовано сучасний стан готельного господарства в Закарпатській області. Розглянуто статистичне оцінювання підприємств готельної сфери регіону, висвітлено тенденції розвитку показників попиту та пропозииії. За допомогою методу екстраполячії здійснено прогнозування розвитку готелів та аналогічних засобів розміщування у Закарпатській області.

Ключові слова: готельне господарство, готелі та аналогічні засоби розміщування, прогнозування, екстраполяиія, коефіцієнт детермінації.
\end{abstract}

Постановка проблеми. Останнім часом туристична галузь набуває все більшого значення для розвитку соціально-економічного життя України та іiі окремих регіонів. 3 точки зору розвитку туристичної індустрії Закарпаття $\epsilon$ одним 3 найбільш перспективних регіонів України, що пояснюється унікальним економікогеографічним розташуванням Закарпатської області, розвинутою транспортною мережею, благодатними природно-кліматичними умовами та культурним потенціалом.

Готельне господарство є невід'ємною складовою туристичної індустрії, виступаючи основою матеріально-технічної бази туризму. Обсяги туристичних потоків і відповідно грошових надходжень залежать, перш за все, від стану готельного бізнесу. Для того, щоб задовольнити всі потреби туриста, відпочиваючого, необхідно забезпечити комфортність його проживання, високу якість обслуговування, тобто створити атмосферу гостинності. В цьому контексті важливим $€$ здійснення аналізу діяльності підприємств готельного господарства та інших засобів розміщування, оцінка особливостей їх функціонування, визначення тенденції їх розвитку на перспективу.

Аналіз останніх досліджень і публікацій. Теоретичну та інформаційну базу дослідження готельної сфери та сучасних тенденцій ії регіонального розвитку відображено в працях вітчизняних учених: С. Байлика [1], М. Бойко [2], Л. Завідної [4], М. Мальської [5], Я. Остапенко [6], В. Папп [7] та ін. Проблеми індустрії

(C) Лендєл М. А., д.е.н., професор, завідувач кафедри менеджменту туристичного та готельноресторанного бізнесу

Морохович В. С., к.ф-м.н., доцент, доцент кафедри природничо-гуманітарних та інформаційних дисциплін, Ужгородський торговельно-економічний інститут КНТЕУ, тел. 0661447530, e-mail: morv77@ukr.net гостинності на регіональному рівні, зокрема статистичного аналізу та прогнозування розвитку підприємств готельного господарства, потребують подальших наукових досліджень.

Формулювання цілей статті. Метою $\epsilon$ дослідження стану готельного господарства Закарпатської області, а також прогнозування розвитку готелів та аналогічних засобів розміщування у регіоні. Для досягнення мети визначені такі завдання:

- проаналізувати стан готельного бізнесу Закарпаття і виявити основні закономірності його розвитку;

- дослідити основні тенденції динаміки показників попиту та пропозиції підприємств готельного господарства;

- застосувати метод екстраполяції для прогнозу розвитку готелів та аналогічних засобів розміщування.

Опис основного матеріалу дослідження. Готельний бізнес є одним з важливих елементів сфери послуг, що виконує функції із забезпечення громадян країни й іноземних гостей житлом, харчуванням, а також різними додатковими послугами. До того ж, готельний бізнес $\epsilon$ прибутковим i рентабельним видом підприємницької діяльності, сприяє розвитку економіки, формує обсяги робіт для різних галузей народного господарства, підвищує міжнародний імідж України як туристичної держави. В свою чергу готельна сфера, як складова галузі туризму в сучасних умовах, $\epsilon$ сектором світової економіки, який активно розвивається, і ефективним джерелом валютних надходжень.

Розміщення в об'єктах готельного господарства - найважливіший елемент рекреаційно-туристичного комплексу. Засобами розміщення є будь-які об'єкти, які надають гостям і туристам коротко- або довготривалі місця для ночівлі і відпочинку. Відповідно до міжнародної класифікації засоби розміщення 
поділяють на дві категорії: колективні та індивідуальні. До колективних засобів розміщення належать готелі та аналогічні засоби розміщення, які мають номерний фонд і надають певний перелік побутових послуг.

До характеристик пропозиції на підприємствах готельного господарства, які обумовлюють спроможність або неспроможність регіону задовольнити в повному обсязі потреби споживачів у послугах розміщування, належать показники їх експлуатаційної можливості, а саме: кількість готелів та аналогічних засобів розміщування, кількість номерів, місткість, житлова площа усіх номерів.

Основні показники

експлуатаційної можливості підприємств готельного господарства Закарпатської області за 2011-2017 pp. відображено в табл. 1.

Таблиця 1

Рівень експлуатаційної можливості підприємств готельного господарства Закарпатської області

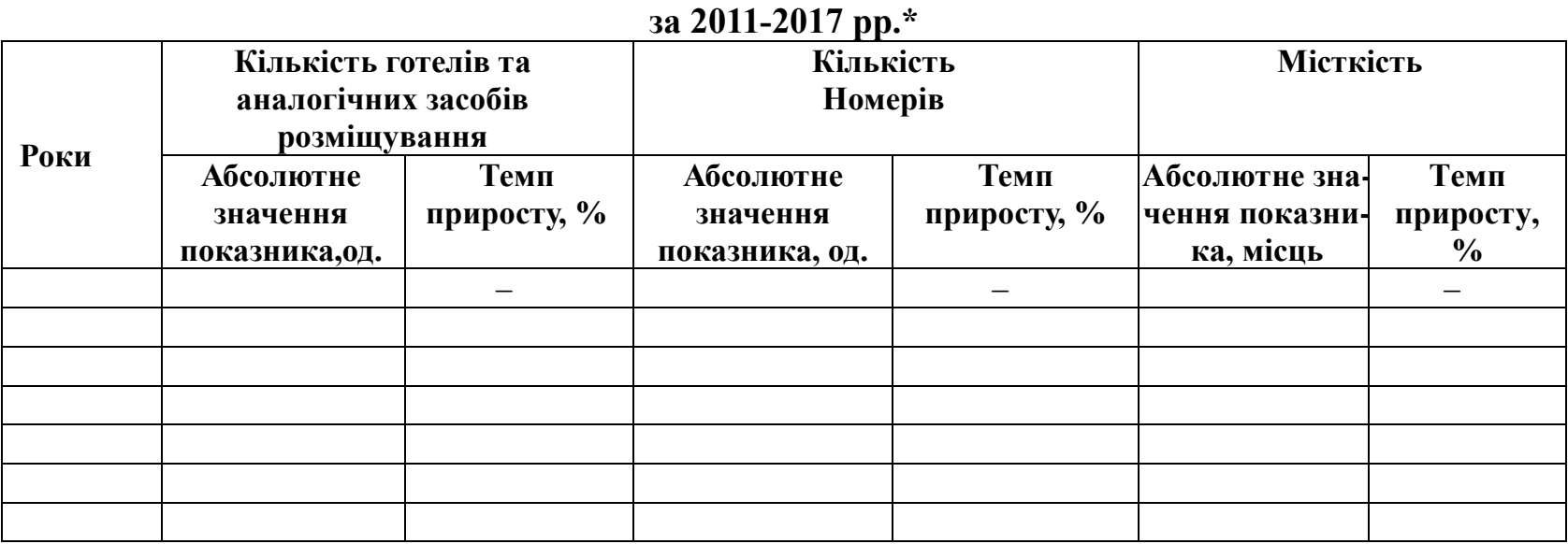

*Сформовано і розраховано за джерелом:[3].

Дані таблиці свідчать, що до 2013 р. усі показники діяльності підприємств готельного господарства демонстрували тенденцію щодо зниження. 2013 р. став переломним, оскільки кількість готелів та аналогічних засобів розміщування збільшилася на $51 \%$, кількість номерів - майже на $62 \%$, місткість - на $58,4 \%$. Починаючи 32014 p. окремі показники експлуатаційної можливості змінюють знак на протилежний. Дослідження підтверджує, що протягом останніх років відбувається укрупнення готелів та аналогічних засобів розміщування, а зменшення показників пов'язано з економіко-політичною та фінансовою нестабільністю країни.

3 індикаторами пропозиції пов'язані показники попиту на послуги підприємств готельного господарства, а саме: кількість осіб, що перебували у закладах та загальний час їх перебування, коефіцієнт використання місткості. На величину зазначених показників впливають різноманітні економічні, соціальні, політичні фактори. Саме тому напрями розвитку показників попиту на послуги підприємств 3 розміщення дещо інші (рис. 1, 2).

Показник кількості осіб (рис. 1), що перебували у закладах області, збільшувався, тобто попит на послуги підприємств готельного господарства зростає. Виключенням став лише 2014 р., що пояснюється нестабільністю політичної та соціально-економічної ситуації в Україні. Впродовж 2011-2017 рр. (рис. 2) не виражені чітко протилежні тенденції, які б ділили період на етапи. Майже в усі роки коефіцієнт використання місткості зростав.

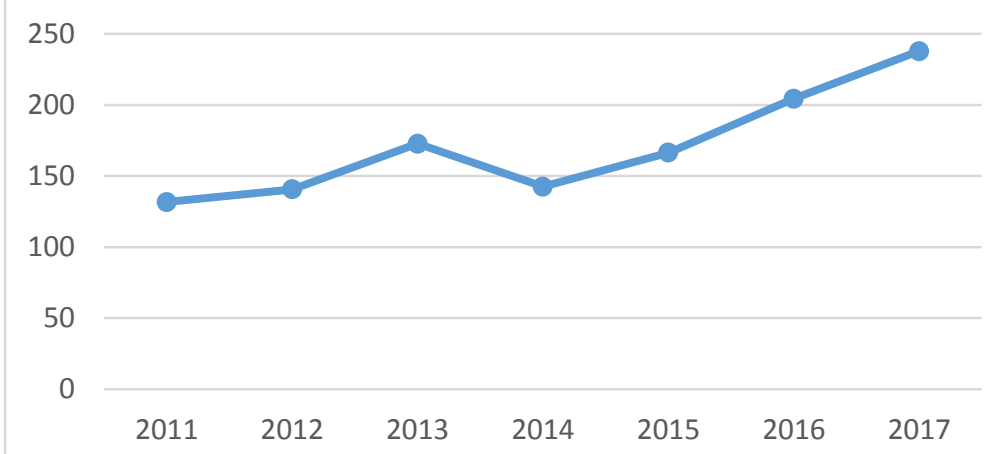

Рис 1. Динаміка кількості осіб, що перебували у готелях та аналогічних засобах розміщування Закарпатської області (2011-2017рр.) 


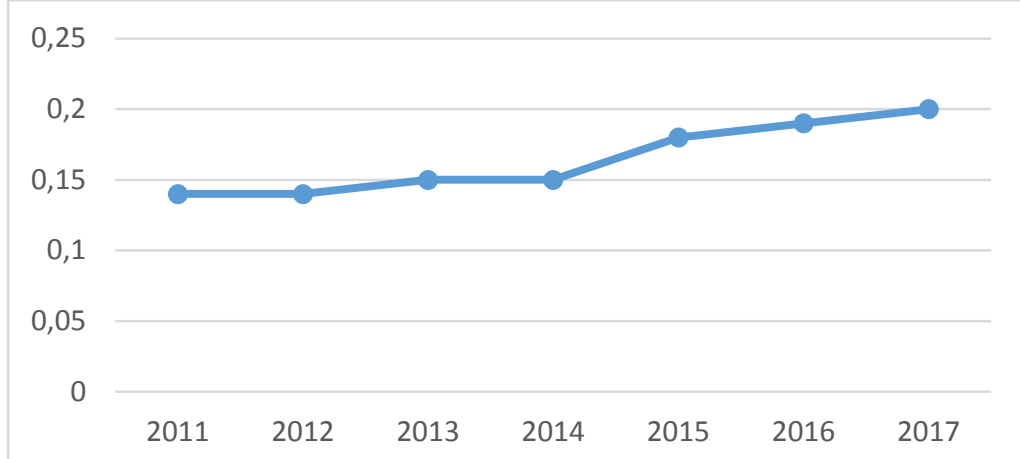

Рис 2. Динаміка коефіціснта використання місткості готелів та аналогічних засобах розміщування Закарпатської області (2011-2017 рр.)

В системі сучасного регіонального механізму готельного бізнесу на основі аналізу й узагальнення тенденцій його функціонування, нами визначено головні причини, що гальмують розвиток галузі. Серед основних $є$ такі:

- недостатній розвиток національної мережі готельних підприємств;

- недостатній рівень матеріально-технічного забезпечення;

- нерівномірність завантаження готельних номерів;

- високі витрати на утримання номерного фонду;

- високі тарифи на готельні послуги;

- низька якість наданих послуг;

- обмежена пропозиція додаткових послуг в межах готельних підприємств;

- конкуренція з боку індивідуальних засобів розміщення не готельного типу;

- низька якість обслуговуючого персоналу готелів;

- потреба відкриття спеціалізованих готельних підприємств;

- відсутність у структурі управління галузі відділу маркетингу;

- слабке програмно-інформаційне забезпечення;

- недостатній рівень управління (менеджмент) - в межах підприємств готельного господарства;

- недостатня державна підтримка готельного бізнесу.

Діагностика функціонування i розвитку готельного бізнесу в регіоні дозволяе здійснити оцінювання його сильних й слабких сторін, виявити можливості та обмежувальні фактори розвитку, систематизувати ці фактори, а результати дослідження використати для прийняття відповідних позитивних економічно обгрунтованих рішень. При цьому слід враховувати такі обмежувальні фактори, як нестабільність, застарілість та недосконалість законодавчої і нормативно-правової бази галузі, політичну нестабільність та неспроможність влади приймати узгоджені рішення на різних рівнях влади, сучасний тимчасовий стан країни в умовах військової агресії 3 боку Російської Федерації, недооцінку значення готельного бізнесу для соціально-економічного розвитку регіону, невідповідність більшості готелів не тільки міжнародним, але й національним стандартам, висока конкуренція 3 боку комфортабельних закладів розміщення у сусідніх країнах Євросоюзу та регіонах, природні катаклізми (повені, зсуви), екологічна безпека.

Аналіз функціонування галузі готельного господарства підтверджує необхідність розроблення і впровадження досконалих методів регулювання процесів готельного бізнесу на всіх рівнях управління 3 врахуванням постійних i дина-мічних змін, що відбуваються в національній економіці.

Для прогнозування розвитку підприємств готельного господарства Закарпатської області застосовано метод екстраполяції тенденцій, як один 3 найпростіших методів прогнозування на перспективу, що дозволяє максимально зменшити невизначеність у процесі прийняття рішень та вибору оптимального варіанту рішень 3 альтернативних. Як формальний критерій для визначення найкращого (оптимального) рівняння тренду, котре доцільно використовувати для прогнозування, використано коефіцієнт достовірності апроксимації $\left(R^{2}\right)$. Відомо, що якщо коефіцієнт апроксимації наближається до 1 , то рівняння тренду може служити прогнозною моделлю.

У процесі дослідження здійснено прогнозні розрахунки на наступні роки для таких показників розвитку готельного господарства Закарпаття - кількість готелів та аналогічних засобів розміщування, кількість номерів i місткість (рис. 3). Вихідні ряди динаміки цих показників охоплюють 2012-2017 pp. 


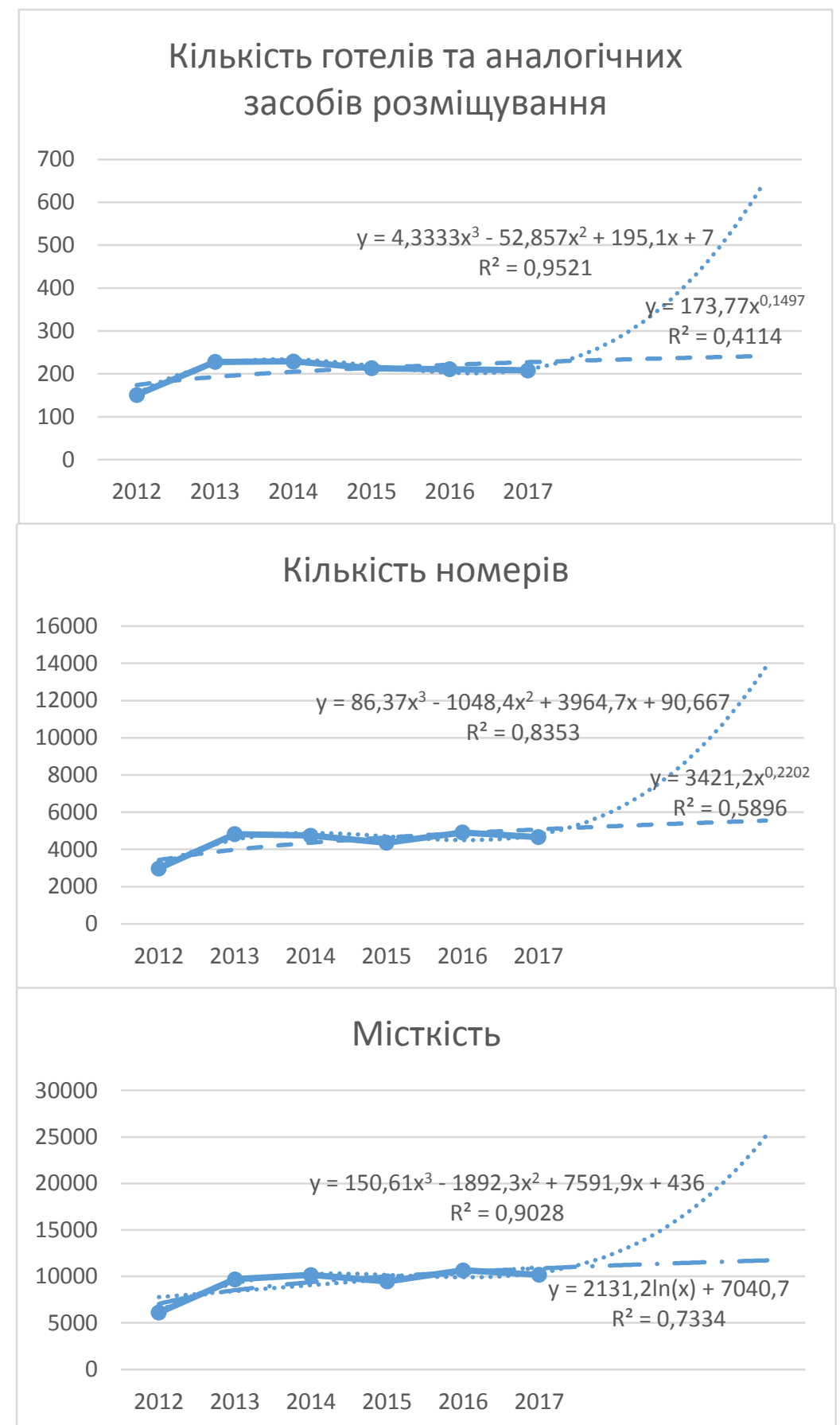

*Джерело: [3]

Рис. 3. Тенденція розвитку підприсмств готельного господарства Закарпатської області*

3 рівняння трендів для прогнозування основних показників розвитку підприємств готельного господарства регіону (рис. 3) випливає, що в динаміці існує тенденція до їх зростання. Як засвідчує аналіз, найбільша величина достовірної апроксимації отримана для поліномів 3 порядку.

За результатами дослідження, за умови збереження тенденції, кількість підприємств готельного господарства у Закарпатській області у 2018 р. становитиме близько 269 та в 2019 р. 403 таких підприємств. Номерний фонд готельного господарства налічуватиме близько 6096 номерів у 2018 р. та 8932 - в 2019 р. відповідно. Кількість місць у готелях і аналогічних засобах розміщування також збільшуватиметься - до 12515 в 2018 р. та 17176 місць в 2019 р. Це свідчить про те, що за даних умов існування готельний бізнес регіону розвиватиметься і розширюватиметься за рахунок малих готелів, хостелів і туристичних баз.

У процесі розроблення пріоритетних напрямів розвитку готельного комплексу регіону постає необхідність дослідження регіональних 
особливостей формування готельного продукту, зокрема, наявних природно-рекреаційних ресурсів і факторів успішного функціонування суб'єктів туристично-рекреаційного бізнесу, врахування яких відіграє фактично вирішальне значення для визначення спеціалізації готельних підприємств. У цьому контексті зростає роль державних органів управління і територіальних громад регіону, основна функція яких полягає у створенні сприятливих умов для функціонування готельного комплексу, 3 метою підвищення ефективності якого доцільно врахувати такі складові регіонального механізму розвитку готельного бізнесу:

- розроблення стратегій розвитку готельного бізнесу на рівні регіону;

- здійснення регіонального районування місць розміщення 3 врахуванням необхідності вирівнювання рекреаційного навантаження в окремих територіях;

- створення маркетингово-консалтингового підрозділу для забезпечення установ рекреації, у тому числі засобів розміщення, аналітичної інформації про попит на послуги і стан ринку;

- удосконалення якості надання послуг;

- удосконалення системи наукових досліджень 3 проблем рекреації, зокрема готельних послуг, на базі науково-технічних програм;

- збільшення обсягів інвестицій у будівництво та реконструкцію готельних підприємств;

- створення багаторівневої системи підготовки та підвищення кваліфікації кадрів готельного бізнесу, оволодіння іноземними мовами;
- узагальнення і використання зарубіжного досвіду ведення готельного бізнесу та приведення його до світових стандартів; - поглиблення міжнародних зв'язків у галузі. Урахування комплексу окреслених проблем і реалізація зазначених заходів сприятиме вирішенню завдань адаптації підприємств готельного бізнесу до нових умов господарювання.

Висновки i перспективи подальших досліджень. Проведений аналіз динаміки кількості готелів у Закарпатській області, а також тенденції зміни готельного фонду дозволяє зробити висновок, що досліджувана галузь економічної діяльності є перспективною сферою капіталовкладень, оскільки розвивається достатньо швидкими темпами, зумовлює рівень зайнятості трудових ресурсів у регіоні, створює матеріальну базу для розвитку туризму i рекреації.

Прогнозні значення основних показників розвитку підприємств готельного господарства регіону засвідчують, що в наступні роки існує тенденція до збільшення кількості готелів та аналогічних засобів розміщування і номерного фонду. Використання екстраполяції на основі рівнянь тренду, отриманих для рядів динаміки показників, які характеризують розвиток підприємств готельного господарства Закарпаття, $\epsilon$ виправданим. Для забезпечення надійності прогнозування доцільним $\epsilon$ максимальне розширення бази фактичних значень.

Подальшими розвідками в цьому напрямі $\epsilon$ моніторинг факторів, які впливають на доходи готельного господарства регіону.

\section{ПЕРЕЛІК ВИКОРИСТАНИХ ДЖЕРЕЛ}

1. Байлик C.І., Писаревський І.М. Організація готельного господарства: підруч. Харків: ХНУМГ ім. О.М. Бекетова, 2015. 329 с.

2. Бойко М.Г. Удосконалення аналізу діяльності підприємств готельного господарства // Вісник КНТЕУ. 2001. № 3. С. 62-67.

3. Державна служба статистики України: регіональна статистика URL: http://www.ukrstat.gov.ua

4. Завідна Л.Д. Аналіз, проблеми та перспективи розвитку готельного господарства в Україні //Вісник ОНУ ім. I.I. Мечникова. 2015. Т.20. Вип. 3. С. 91-95.

5. Мальська М.П., Пандяк І.Г. Готельний бізнес: теорія та практика: підруч. К.: Центр учбової літератури, 2012. $472 \mathrm{c}$.

6. Остапенко Я.О. Статистичний аналіз підприємств готельного господарства та прогнозування його розвитку//Глобальні та національні проблеми економіки. 2015. Вип. 8. С. 1216-1221.

7. Папп В.В. Роль готельного господарства у розвитку туризму в регіоні // Науковий вісник Ужгородського університету. Серія «Економіка». 2015. №2 (46). С. 207-212.

\section{REFERENCES}

1. Bajlyk, S.I., \& Pysarevs'ky, I.M. (2015). Organizacija gotel'nogo gospodarstva [Organization of the hotel economy]. Harkiv: HNUMG im. O.M. Beketova [in Ukranian].

2. Boyko, M.G. (2001). Udoskonalennja analizu dijal'nosti pidpryjemstv gotel'nogo gospodarstva [Improvement of the analysis activity of enterprises of hotel economy]. Visnyk of KNTEU - Bulletin of KNTEU, 3, 62-67 [in Ukranian].

3. Derzhavna sluzhba statystyky Ukrajiny: regional'na statystyka [State Statistics Service of Ukraine: regional statistics]. (n.d.). Retrieved from: http://www.ukrstat.gov.ua [in Ukranian]. 
4. Zavidna, L.D. (2015). Analiz, problemy ta perspektyvy rozvytku gotel'nogo gospodarstva v Ukrajini [Analysis, problems and prospects of the hotel industry in Ukraine].Visnyk ONU im. I.I. Mechnykova - Bulletin of I.I. Mechnykov ONU, 20, 3, 91-95 [in Ukranian].

5. Mal's'ka, M.P., \& Pandjak, I.G. (2012). Gotel'nyj biznes: teorija ta praktyka [Hotel business: theory and practice]. K.: Centr uchbovoji literatury [in Ukranian].

6. Ostapenko, Ja.O. (2015). Statystychnyj analiz pidpryjemstv gotel'nogo gospodarstva ta prognozuvannja jogo rozvytku [Statistical analysis of the hotel industry and prognosis of its development]. Global'ni ta nacional'ni problemy ekonomiky - Global and national problems of Ukraine, 8, 1216-1221 [in Ukranian].

7. Papp, V.V. (2015). Rol' gotel'nogo gospodarstva u rozvytku turyzmu v regioni [The role of the hotel industry in the development of tourism in the region]. Naukovyj visnyk Uzhgorods'kogo universytetu. Serija «Ekonomika» - Scientific bulletin of Uzhhorod university. Series «Economics», 2 (46), 207-212 [in Ukranian].

Одержано 12.03.2019 